\title{
The Impact of Crisis Management Strategy on the Performance of the Employees of Arab Potash Company "an Applied Study"
}

\author{
${ }^{1}$ Dr. Amal Yassin Al-Majali, ${ }^{2}$ Dr. Hamza Farhan Tamimi \\ ${ }^{1}$ Balqa Applied University Jordan \\ ${ }^{2}$ Ministry of Finance / Director of Finance/ Jordan
}

\begin{abstract}
The study aimed at recognizing the crisis management strategy and its impact on in the performance of employees of Arab Potash company. The problem with the study is that the Arab Potash Company is under internal and external pressure can lead to a real crisis affecting the performance of employees and the resulting disruption of production and lower profits. To achieve the aim of the study self-administrated questionnaire was used to collect the data. It was developed and distributed to as ample of (248) individuals. However, 8 copies were excluded for not being suitable for statistical analysis, so that the number of questionable questionnaires eligible for statistical analysis equal (240) copies. This data has been analyzed using SPSS 16. The study concluded many conclusions from them, potash company management teams used to work as a management methods to solve the problems they face, draw upon the company's management strategy change course when faced by crises is clear-cut, with the company's management is convinced that the tactical reserve strategy necessary to respond to crises. The study many of the recommendations, including, the need for concerted government and private efforts to reach appropriate solutions to mitigate the crises facing the Jordanian companies, the need to provide a center for the preparation of leaders and managers of companies, and equip them with the necessary capacity to deal with crises. The study suggested a more specialized in the field of crisis management studies
\end{abstract}

Keywords: crisis management strategy, performance of employees, Arab Potash Company

\section{INTRODUCTION :}

There is no doubt that we live in a large world characterized by rapid changes, and we face many challenges and developments, all of which constitute real crises at the level of individuals, groups, organizations and States.

In order to be able to overcome these crises we have to have systematic and clear strategies that help us to manage these crises and deal with them in a scientific manner based on the available knowledge, experience and capabilities with a successful management style, through plans and strategies to manage crises rationally and objectively ensure positive results for the individual or organization that We work on it as well.

The Hashemite Kingdom of Jordan through its distinguished geographic location in the heart of the Arab World is vulnerable to external or internal crises like other countries, whether political or economic. Its public and private institutions are not far from crises, risks and challenges in the age of information explosion and keeping pace with rapid global developments.
Hence, there is a need to search for modern and sophisticated strategies to manage these crises and the problems resulting from them, in a correct scientific way and a comprehensive manner, which includes understanding, perception and setting time plans arising from crisis management strategies.

So, this study seeks to identify the impact of these strategies of crisis management in the performance of the employees of Arab Potash Company in Hashemite Kingdom of Jordan.

\section{The Problem of The Study:}

The problem of the study is summarized in the anticipation of the researcher of the exposure of Arab Potash Company to external and internal pressures that could lead to a real crisis that affect the performance of the workers resulting especially a paralyzed production and a lower profits and in general affecting its control ability. This matter causes the company to look for alternatives and strategies to manage this crisis in a way that will reflect positively on the performance of the workers 
to increase the productivity and to maximize the profits.

So, the purpose of the study is to identify the impact of the strategies of crisis management on the performance of the workers of Arab Potash Company.

Hence, the problem of the study is demonstrated by the main question:

What are the most important strategies of crisis management (Changing Path Strategy, Crisis Fragmentation Strategy, Group work Strategy, Crisis Containment Strategy, Reserve Mobilization Strategy, Crisis Exhausting Strategy) that affect the performance of the workers ( increasing productivity and profit maximization) at Arab Potash Company?

\section{This main question is branched into the following sub-questions:}

1. What is the impact of Changing Path Strategy on the performance (productivity increase and profit maximization) of the workers of Arab Potash Company?

2. What is the impact of Reserve Mobilization Strategy on the performance (productivity increase and profit maximization) of the workers of Arab Potash Company?

3. What is the impact of Group work Strategy on the performance (productivity increase and profit maximization) of the workers of Arab Potash Company?

4. What is the impact of Crisis Fragmentation Strategy on the performance (productivity increase and profit maximization) of the workers of Arab Potash Company?

5. What is the impact of Crisis Containment Strategy on the performance (productivity increase and profit maximization) of the workers of Arab Potash Company?

6. What is the impact of Crisis Exhausting Strategy on the performance (productivity increase and profit maximization) of the workers of Arab Potash Company?

\section{THE IMPORTANCE OF THE STUDY:}

This study derives its importance from the fact that it is looking at an important and vital subject which is the impact of the crisis management strategy on the performance of the employees of the Arab Potash Company. The importance of this study is highlighted as it is considered one of the few studies (according to researchers) that is specialized in studying the strategy of crisis management in the company, which is one of the largest companies in the Arab world. The importance of this study lies in tracing the modern management methods in terms of identifying the possibility of problems or crisis occurrence that may affect the company's business process and the level of damage resulting from the lack of interest or making any decision that may lead to a reduction in productivity or a decrease in profits and affected by the workers and the dealers in general.

This company is considered as a main supporter of the Jordanian economy at production, export and employment levels, and its contribution to local and national development. The importance of this study is highlighted in the practical aspect in terms of submitting recommendations resulting from the study to the decision makers working in the Arab Potash Company, as well as in other similar companies, and to identify the impact of the company's implementation of crisis management strategies on its workers to ensure the sustainability of the company's work.

\section{THE OBJECTIVE OF THE STUDY:}

This study aims at identifying the impact of the strategies of crisis management on the performance of the workers of Arab Potash Company. This objective is divided into the following subobjectives:

1. To identify the impact of Changing Path Strategy on the performance of the workers of Arab Potash Company.

2. To identify the impact of Reserve Mobilization Strategy on the performance of the workers of Arab Potash Company.

3. To identify the impact of Group work Strategy on the performance of the workers of Arab Potash Company.

4. To identify the impact of Crisis Fragmentation Strategy on the performance of the workers of Arab Potash Company.

5. To identify the impact of Crisis Containment Strategy on the performance of the workers of Arab Potash Company.

6. To identify the impact of Crisis Exhausting Strategy on the performance of the workers of Arab Potash Company.

\section{THE HYPOTHESES OF THE STUDY:}

The study has one main null hypothesis that is divided into 6 sub-hypotheses.

The main Hypothesis $\left(\mathrm{H}_{0} 1\right)$ : there is no statistically significant impact at $(\alpha=0.05)$ of the strategy of crisis management (in terms of its dimensions) in improving the performance of the workers of Arab Potash Company. 
From this main hypothesis, the following subhypotheses are emerged:

First sub-hypothesis $\left(\mathrm{H}_{0} 1-1\right)$ : there is no statistically significant impact at $(\alpha=0.05)$ of Changing Path Strategy in improving the performance of the workers of Arab Potash Company.

Second sub-hypothesis $\left(\mathrm{H}_{0} 1-2\right)$ : there is no statistically significant impact at $(\alpha=0.05)$ of Reserve Mobilization Strategy in improving the performance of the workers of Arab Potash Company.

Third sub-hypothesis $\left(\mathrm{H}_{0} 1-3\right)$ : there is no statistically significant impact at $(\alpha=0.05)$ of of Group work Strategy in improving the performance of the workers of Arab Potash Company.

Fourth sub-hypothesis $\left(\mathrm{H}_{0} 1-4\right)$ : there is no statistically significant impact at $(\alpha=0.05)$ of Crisis Fig. (1) The Study Model

\section{Dependent Variable Independent Variables}

Fragmentation Strategy in improving the performance of the workers of Arab Potash Company.

Fifth sub-hypothesis $\left(\mathrm{H}_{0} 1-5\right)$ : there is no statistically significant impact at $(\alpha=0.05)$ of Crisis Containment Strategy in improving the performance of the workers of Arab Potash Company.

Sixth sub-hypothesis $\left(\mathrm{H}_{0} 1-6\right)$ : there is no statistically significant impact at $(\alpha=0.05)$ of Crisis Exhausting Strategy in improving the performance of the workers of Arab Potash Company.

\section{The STUdy Model:}

The dependent and independent variables of the study could be determined from the following study model

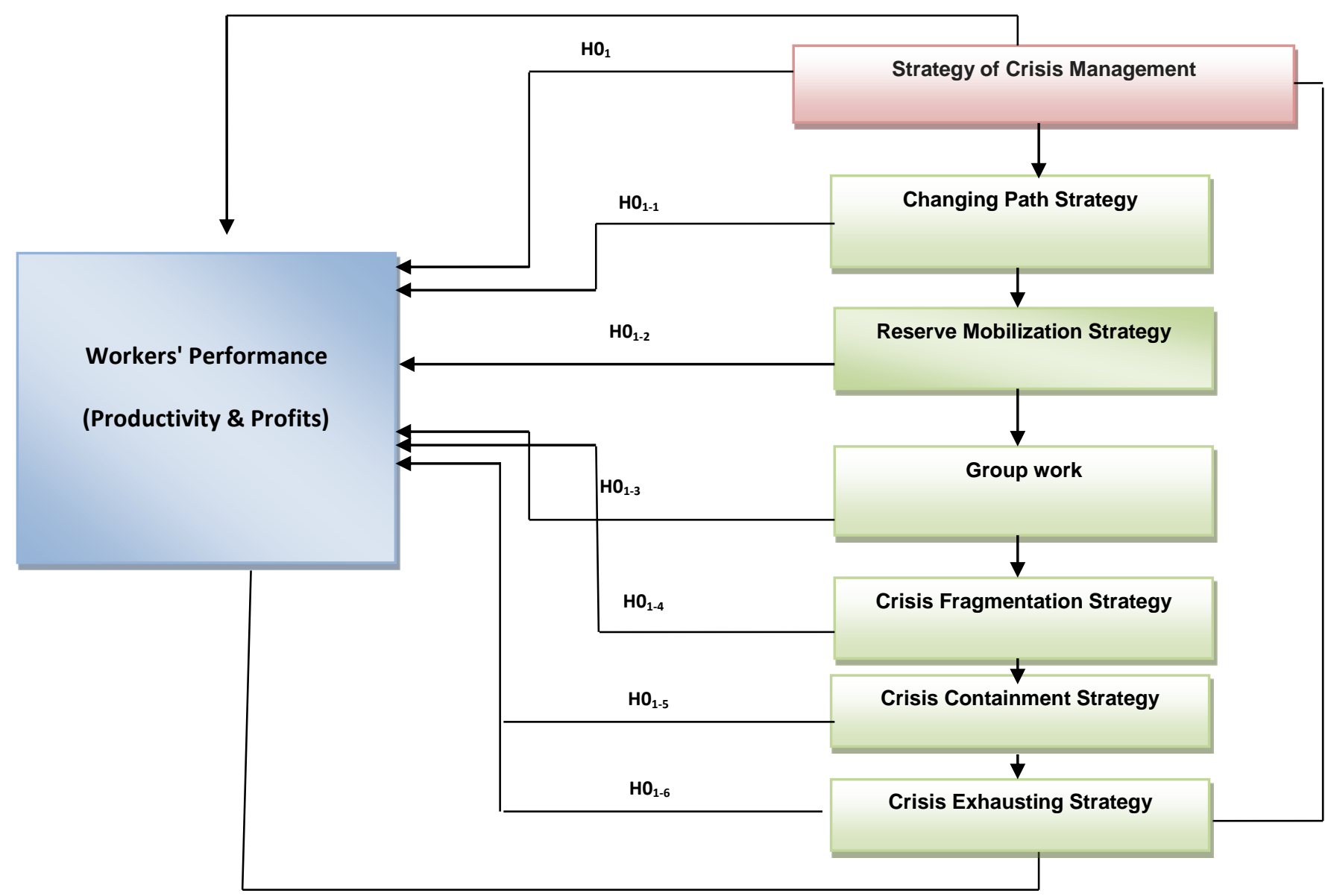

Source: done by the researchers 2015

\section{METHODOLOGY OF THE STUDY:}

The analytical descriptive approach was used to identify the impact of the crisis management strategy on the performance of the employees of the Arab Potash Company, as well as the statistical treatment of the variables of the study and its correlations according to the questions and the hypotheses of the study and the results of the study and its recommendations.

\section{Data Collection Tool:}

The researchers have used two types of data: 
A. The primary data: the necessary data related to hypotheses testing and descriptive analyses of the variables of the study were collected using a developed questionnaire. The first part includes data that are related to demographic information such as: gender, years of experience, age. Scientific qualification, current position. The second part included 7 fields that are: Changing Path Strategy, Crisis Fragmentation Strategy, Group work Strategy, Crisis Containment Strategy, Reserve Mobilization Strategy, Crisis Exhausting Strategy and employees performance. The questionnaire was based on a five-point Likert scale where the responses were specified by 5 levels: strongly agree (5 points), agree (4 points), neutral ( 3 points), disagree ( 2 points) and strongly disagree (1 point.) The total number of the items of the questionnaire equals to 34 items. The questionnaire was designed carefully to ensure clarity, sequence and simplicity of the items to be adopted as the tool of the study.

B. The secondary data: data related to theoretical framework of the study was collected by referring to scientific books, studies, previous research and foreign studies.

\section{Previous STUdies:}

Fahad Alnagi Study (2012) entitled "The Effect of Modern Crises Management Strategies on Marketing Performance (A field study on the Human Pharmaceutical Industrial Companies in Amman Metropolitan Area)." The study aims to identify the effect of modern crises management strategies on marketing performance for the human pharmaceutical industrial companies in Amman Metropolitan Area. The study depends on a null hypothesis that says "there is a statistically significant impact at $\alpha=0.05$ of crisis management strategies and performance management, the study was based on analytical descriptive approach. The most important conclusion of the study is the new strategies of crisis management have an impact on marketing performance. In the end of the study the researcher make a group of recommendations the most prominent is that there should be a specialized section in pharmaceutical human industrial companies in Amman Greater municipality that cares about crisis management.

Mohammad study (2011) entitled " Crises Management Strategy: A Conceptual Framework from Islamic Perspective," aimed to identify the strategies of crises management from Islamic perspective, using documentary descriptive approach based on related previous studies and books. The researcher tackled the new concept of crisis, its characteristics, phases and effects. The study concluded that dealing with crises requires bypassing the traditional solution ways to follow more innovative ways. Also the study found that some crises accompany the main crisis such as Media crises, psychological crises, and technical crises. The researcher recommended the need to provide experts of the crisis beforehand, in order to build the necessary trust relations and make a decisive decision.

Bernstein study (2012) entitled "Crisis Management and Sports in the Age of Social Media: A Case Study Analysis of the Tiger Woods Scandal," focused on crisis management strategies and their application to the American professional golfer Tiger Woods scandal. A case study analysis was conducted of Woods' official press statements following the scandal to evaluate what strategies and tactics his crisis management team used and how successful they were in restoring Woods' image. Data for this research were collected through Tiger Woods' press statements following the break of his 2009 sex scandal. It included the examination of eight statements, all released from the official Tiger Woods website, that ranged from November 29, 2009, two days after the initial accident, until August 23, 2010. the results of the study have demonstrated that Mortification Strategy was the most used strategy in the crisis as it is based on admitting of mistakes and asking forgiveness which conveys treatment, repentance and correction. the crisis management team has succeeded through this strategy to avoid talking about the scandal and to make the fans to discuss the level of the player in golf.

Alihmad study (2009) entitled "Analyzing the Effect of Business Crisis Management Strategies on Organizational Performance of Palestinian Companies," aimed to identify the impact of crises management strategies on the performance (marketing and finance) of Palestinian companies where the financial data during 2000-2009 were used. The study was based on a null hypothesis that states "there is no statistically significant impact at $\alpha \leq 0.05$ of crises management on organizational performance of Palestinian companies." the study adopted the analytical descriptive approach, and concluded that the strategies of crises management have no impact on the organizational performance (marketing and finance.) the most important recommendation of the study is to establish a specialized department for crises management in the organization. 
Sebti Study (2002) entitled "crisis management in the Jordanian industrial organizations: a field study from managers' perspective," aimed to explore to what extent are the industrial organizations ready for managing the crises also to determine the impact of the following factors on cries management readiness: information \& communication, the clarity of tasks and responsibilities, rewards, coordination among departments, and available resources. the results of the study have shown that the industrial organizations are vulnerable to interior crises more than the exterior ones and there exists level levels of crises management with high rates and are ranked in descent order: signal detection, recovery, damage containment and limitation, preparation and prevention. Among the most important recommendations of the study was integrated team works of employees from all departments should be constituted and trained with continuous way to confront the potential crises.

Suifan and AlTit Study (2009) entitled The Practice of Change strategies in Encountering Crises and its Impact on Corporate Performance: A Field Study on the Jordanian Banking Sector,"

Aimed to is to describe the impact of the practice of change strategies in encountering crises and its impact on corporate performance in the Jordanian banking sector. The sample study consisted of (209) individuals working in four banks: Arab Bank, Housing Bank for Trade and Finance, Bank of Jordan and Bank Society-General, and was selected by using the stratified random sampling method. A questionnaire was developed to measure the study variables which had the acceptable validity and reliability. Appropriate statistical methods were also used to answer the study questions and to test the hypotheses. The study concluded a set of results, the most important are: The degree of practicing change strategies in encountering crises in - the Jordanian banking sector was high, where the degree of practicing the empirical rational and normative reductive strategies was also high, whereas the degree of practicing the power coercive strategy was medium. The level of corporate performance in the Jordanian banking sector was high. In light of these results, the study presented many recommendations; the most important one is enhancing the practice of empirical rational and normative reductive strategies and trying to merge them in the Jordanian banking sector; and avoiding the use of power coercive strategy.

Alkshali and Al-Qutob Study (2007) entitled "Effectiveness of Management Information Systems and Their Impact on Crisis Management: Field Study on Jordanian Industrial Companies," aimed to explore the extent of the MIS effectiveness in managing crises of Jordanian Industrial firms. The study was based upon on a null hypothesis stating "there is no statistically significant impact at $\alpha \leq 0.05$ of Management Information Systems on Crisis Management as it adopted the descriptive analytical approach. The results showed that the various elements of MIS effectiveness, as a whole, had a significant impact on managers' capabilities of managing the crises they encountered. Also, the various MIS elements had different and varying impacts on managers' capabilities to manage each stage of crisis. The elements which had the greatest impact were: the usability, which had an impact on managing all stages of crisis except that of early warning signals detection stage. The second element was the response to new changes, which had an impact on managing all stages excluding the learning stage. The study provided several recommendations to help managers of these firms to manage future crisis successfully.

Yamamoto and Şekeroğlu Study (2011) entitled " Crisis management in the Turkish leather industry," aimer to examine the tendencies of the Turkish leather industry regarding the crisis management with a questionnaire study, pursuing to identify the thoughts of business executives regarding the crisis. The study was based upon on a null hypothesis stating "there is no statistically significant impact at $\alpha \leq 0.05$ of crisis management on improving performance of Turkish leather industrial companies. The study concluded that most of the companies in the Turkish Leather industry do not have a commonly-agreed institutional policy to be implemented in emergencies regarding crisis management, they are unaware of tested methods and means, and they do not care much for the issues such as making available a team of staff to immediately act against an unexpected situation and taking preliminary measures.

Cooley and Cooley Study (2011) entitled "An examination of the situational crisis communication theory through the General Motors bankruptcy," aimed to analyze the crisis 
communication strategy selection of General Motors (GM) through the company's filing for chapter 11 . The study uses Coombs situational crisis communication theory (SCCT) model as a framework for understanding and suggesting future crisis communication strategy selections. The study found GM followed the guidelines outlined by the SCCT model in successfully negotiating reputational management through a financial crisis. The study suggests companies facing similar crises should follow similar strategy selection; however Deal Cluster strategy selection should take into account leadership transitions.

\section{Manning Study (2004) entitled " Strategic} Management of Crises in Small and Medium Businesses," aimed to analyze what strategies small and medium businesses actually adopt when confronted with a major crisis such as a fire, flood or similar catastrophe, and determine what factors proved vital to the survival of the business. The study was based upon on a null hypothesis stating "there is no statistically significant impact at $\alpha \leq 0.05$ of Strategic Management of Crises on in Small and Medium Businesses as it adopted the descriptive analytical approach. The study found that the owners and managers of small and medium businesses rated the development of a Crisis Management Model as a crucial management tool to assist them to fight for the survival of their business following a crisis. Even those owners that found that the business, for whatever reason, could not be saved, needed to develop a modified plan that strategically addressed the owners' withdrawal from the enterprise. The study recommended testing of the Crisis Management Model for Small and Medium Enterprises needs further research.

\section{Procedural Definitions:}

Crisis: A potential or sudden event that threatens the life of the organization or the lives of workers that is difficult to control and has positive or negative effects depending on the way we deal with the crisis .

Crisis management Strategy: are the ways followed by the decision-maker at the highest levels of management at the time of the crisis, utilizing the appropriate strategy depending on the type and nature of the crisis and according to the available possibilities and represented by (Changing Path Strategy, Crisis Fragmentation Strategy, Group work Strategy, Crisis Containment Strategy, Reserve Mobilization Strategy, Crisis Exhausting Strategy).

Strategic Management: A way of thinking, a style of management, a methodology for making strategic decisions, and a task of senior management and strategic manager. It is a creative process of rational analysis, and the intuitive perception of humanity. It is also a continuous dynamic process that seeks to achieve the organization's mission by managing and directing its available resources efficiently and effectively, and the ability to meet the challenges of a changing business environment to achieve the best.

Crisis Management: Knowledge of the causes of the emergence of the crisis and the use of scientific, practical and planned tools to try to control and address it through the exploitation of its positive features and exclude the negative ones, depending on at which stage the crisis is.

Changing Path Strategy: It is the strategy followed in the event of a strong crisis that is difficult to freeze or stop, by turning its course to positive aspects and directing it to another direction

Crisis Fragmentation Strategy: This strategy includes full knowledge of the causes of the crisis, its advantages and disadvantages, and its division into viable parts for the development of successful solutions for the benefit of the work and employees of the Organization.

Group work Strategy: The strategy is represented by working as a group of specialists and experts in various fields of the various ramifications of the crisis, where all aspects are taken into account and not to overlook any part of the proposals contained in the solution (Maher, 2006, p. 95).

Crisis Containment Strategy: this strategy focuses on preventing the crisis to spread so that it is passed to its importance and absorbed according to the stage in which it exists .

Reserve Mobilization Strategy: Provide the minimum reserve for the operation of the production process and not stop due to lack of supply of any input production.

Crisis Exhausting Strategy: Know the causes of the crisis and its implications and work to end the crisis completely.

Maximizing Production: Maximum capacity of quantities produced according to the plan and the required specifications.

Maximizing Profits: Maximizing profits by increasing sales volume and reducing costs, taking into account the sustainability of these profits over time.

\section{FIELDS OF THE STUDY:}

The fields of study are reflected in the following: 1.Human Field: This study is limited to employees of the Arab Potash Company. 
2.Time domain: This research covers the period from 2005 to 2015. 3.Spatial domain: This study is conducted on the Arab Potash Company, in the governorate of Karak - Southern Valley region.

\section{THEORETICAL FRAMEWORK:}

\section{THE FIRST TOPIC: THE CONCEPT OF THE CRISIS:}

The concept of crisis is used in many studies in the wrong place and is confused with many other concepts. It is common knowledge that the atmosphere of the crisis is affecting the world in all fields, cultural, social and economic. This requires the need to find a concept for this international phenomenon (Williams, 1976, P.76). There is no doubt that many international phenomena are very complex and cannot be understood if we do not understand the complex nature of the international system and the changes that have occurred in this system that cannot be ignored when studying such important phenomena, especially if we know that These changes have been and continue to be an important factor in the emergence of tensions and conflicts that are a direct cause of international crises (Mohammad, 1996). At the individual level there is an emotional crisis or a financial crisis and at the level of one country there is the economic crisis and the constitutional crisis (Alkayali and Zaheri, no date). From the previous discussion and since crisis is a different and recurring phenomenon, it is difficult to find a definition that is accurate and clear. Any attempt to define the concept of the crisis has many problems, because this term is subjected to individual and heterogeneous use, but this does not prevent us from identifying the most important linguistic meanings of the term (Crisis). The linguistic meanings of the term crisis varied according to different jurisdictions.

Charles McClelland (1972) defines crisis as particular type of expression in the nature of the relationship between the parties of the conflict and this shift is attributed to the nature of the mutual acts between them when the crisis is escalated on the acts of armament due to the use of force or threat, but in the case of reduced severity of the crisis, the rate of acts of armistice begins to decline and replaced by attacks Speeches (e.g., protests) to cover each party's concessions.

The crisis, according to Bieber, is a turning point in unstable situations that can lead to undesirable results if the parties concerned are unwilling or unable to contain or mitigate their risks.

In summary, the crisis means a threat and a foreseeable or unexpected threat to the goals, values, beliefs and property of individuals, organizations and States that limit the decisionmaking process.

\section{THE CONCEPT OF CRISES MANAGEMENT:}

The continual managerial process that is concerned with forecasting potential crises through sensing and monitoring internal or external environmental changes that generate crises and mobilizing the available resources to prevent or to prepare to deal with crises in the most efficient and effective manner, in order to achieve the least possible damage to the organization (Ahmed, 2002).

\section{Crisis Characteristics}

\section{Crisis is characterized by the following:}

1. Element of surprise: For example, you enter the office in the morning to find the computer has stopped working, to lose all the plans and information that you have spent weeks to prepare it.

2. Insufficient Information: Not knowing the reason, not recognizing the proper behavior, so that it can be the first crisis of its kind that you may encounter.

3. Escalating flow of events: Events continue to add the diphtheria, for example, the device stops working only when needed, and the school wall does not fall only students at home.

4. Perceived or real loss of control: All crisis events fall outside the scope of individual capabilities and expectations and are deviated from the normal routine of the institution.

5. State of stress and anxiety: Where the manager issued violent decisions: ending the service of anyone involved in the crisis, or quarrelling with his assistants, or submitting his resignation.

6. No immediate obvious solutions: The crisis does not wait for the manager to reach a careful solution, but threatens to destroy the reputation of the organization and its assets, in the blink of an eye, and there must be a trade-off between a limited number of costly solutions to choose the least harmful one (Alhamlawi, 1997).

\section{The DIMENSIONS OF CRISIS:}

\section{There are two dimensions of Crises:}

- The problem: A kind of sudden, unforeseen change that requires an effective mix of management planning, containment and management skills. 
- Conflict: It involves conflict of interests or will of two or more parties, and requires special skills for conflict management and negotiation.

\section{Methods of resolution and handling of crisis:}

- The first method: a method that addresses the crisis and finds successful solutions and final reasons for the purpose of preventing the aggravation and increase of severity (Albayyati, 1994). In other words, this method represents the containment of the crisis.

- The second method is to freeze or destroy the crisis and to keep it in a stable position that does not increase its risks and threats. In other words, countries seek to maintain the existence of the crisis and its associated effects, with a comprehensive inventory of all the expected prospects and limiting possible alternatives to confrontation (Alammari, 1987).

- The third method: dealing with the crisis on the grounds that crisis could be undesirable for some countries but other countries are expecting it as they see the crisis as a situation that can be invested and utilized and must identify the preventive procedures and measures to address similar problems (Mohammad, 1996).

- In crisis, there are those who find the motivation to develop and innovate new policies that are needed primarily but not under normal circumstances (Haqqi, 1985).

- Based on the above, the methods of managing the international crisis depend to a large extent on the wording or way in which decision makers are aware of the crisis situation and the nature of the assessment reached by the decision-makers.

\section{WAYS TO SOLVE THE CRISIS:}

Which are suitable for the spirit of the times and compatible with its variables and the most important of these methods are:

- Group work method: It is one of the most widely used methods at present. It requires more than one expert and specialist in different fields to calculate each factor and to determine the required course of action with each worker.

These ways are either temporary or permanent work methods of specialized cadres that are formed, and are configured to cope with crises and emergencies.

- Reserve Mobilization method to deal with crisis: Where weaknesses and crisis sources are identified, a precautionary reserve is created that can be used if the crisis occurs. This method is often used in industrial organizations when a raw material crisis or lack of liquidity occurs.
- The democratic participation method to deal with crises: the most effective and used way when the crisis is related to individuals or be centered on a human element. This means the disclosure of the crisis and its seriousness and how to deal with it between the boss and subordinates in a transparent and democratic way.

- The containment method: the siege of the crisis in a narrow and limited scope for example the labor crises where the method of dialogue and understanding is used with leaders of those crises.

- Escalation of the crisis: used when the crisis is not clear and when there is a conglomerate at the stage of the formation of the crisis so that the one who face the situation, intends to escalate the crisis to dismantle this bloc and to reduce the pressure of the crisis.

- Crisis Exhausting method: emptying the crisis of its content. It is one of the most successful methods used where each crisis has a specific content that may be political, social, religious, economic, cultural, administrative or other type, and the task of the manager is to make the crisis loses its identity and content and thus lose the strength of the crisis pressures.

- The method of fragmentation of crises: It is best if the crises are severe and dangerous. This method depends on studying all aspects of the crisis to know the forces formed for the alliances of the crisis and determining the framework of conflicting interests and the potential benefits of members of these alliances and then hitting it by contrived leaders and fabricated gains for these trends that are contrary to the continuation of crisis alliances. So the big crisis will turn into small, fragmented crises.

\section{The most important causes of crises:}

The crisis is in fact the administrative failure of the decision-maker due to a certain administrative imbalance or lack of experience or modernity of knowledge or all these reasons, hence the frequent occurrence of crises in fact requires the change of administrators of the administrative entity where the crisis occurred.

\section{Crisis management requirements:}

1.Selection of the management team (leadership):

2.Speed in making a decision crisis:

3.Accuracy and adequacy of information: Crisis management requires the gathering of the necessary information due to its influential role in 
the crisis trends. The assessment processes of the parties of the crisis depend on the capabilities and intentions of some of them on the available information on the situation of the crisis.

4.Planning: The success of crisis management depends on the planning process in all its dimensions. This process, which deals with the study of real capabilities and the clear definition of objectives, is essentially a measure aimed at facing the future with organized plans. Therefore, successful management of the crisis requires a clear, precise plan preceding implementation process.

\section{The Employee Performance:}

Performance is represented by organizational behavior in the light of the principles of management, so as to achieve management functions (decision making, planning, organizing, supervising, directing, leading and controlling) rationally (i.e., with the least effort, time and costs). Performance is: the conduct of a person, to achieve a specific goal, it may be satisfying a particular need or solving a problem or planning a project. Within the institution or organization, performance could be defined as the valuable outputs $t$ generated by the system in the form of goods and services.

Job performance is also important because of its relevance to the efficiency and effectiveness of organizations in achieving their objectives and to achieve their vision, goals and core values, which causes the organizations to focus and concentrate on human resources management in achieving the objectives of the organizations.

\section{Factors affecting performance:}

Al-Salami (2005) sees two main factors that have a significant impact on performance. These two factors can be summarized as follows:

1. Technical factors: represented in technological progress, raw materials, organizational structure of work, methods and methods of work. Technical aspects have a clear and direct impact on the efficiency of the organization and individuals, the quality and quantity of machines and the practical methods and techniques used in the work all affect the level of productivity and performance in general.

2. Human factors: The ability to perform the actual work, including: knowledge, education and experience, in addition to training, skill and personal ability, as well as the desire to work, which is determined through physical working conditions, social working conditions and the needs and desires of individuals.

There are other factors that contribute to improving the efficiency of the organization and improving the level of performance of its members through the development and activation of the role of employees in the organization, including: incentives and participation in decision-making and training.

\section{FIELD STUDY PROCEDURES: \\ Study population and its Sample:}

The population of the study consisted of all 2469 employees of Arab Potash Company. The study sample consisted of $10 \%$ of the entire study population. Thus, the sample comprised (248) individuals and a previously prepared questionnaire was distributed to each individual in the sample. However, 8 copies were excluded for not being suitable for statistical analysis, so that the number of questionable questionnaires eligible for statistical analysis equal (240) copies. This data has been analyzed using SPSS package version 16 to achieve the goals and objectives of this study.

\section{Characteristics of the study sample:}

A number of demographic factors have been selected, which are related to personal and functional matters so as to clarify certain things related to the study sample. The results indicated in the following tables have show the characteristics of the sample members in terms of gender, number of years of experience, age, academic qualification, job position.

\section{Study procedures}

1- The researchers distributed copies of the questionnaire (the study tool) to the individuals of the study sample represented by a group of employees of Arab Potash Company; the researchers discussed with them the method of implementation by clarifying the instructions to them orally so the respondent adds the mark $(\sqrt{ })$ in the right place.

2. The data were reviewed, checked and coded to facilitate analysis and storing to the computer. The data were analyzed using the SPSS Package (16).

\section{Statistical treatment:}

To achieve the objectives of the study, the following statistical methods were used:

A. Descriptive statistics: In order to present the characteristics of the sample members and describe their answers, by using the following: Percentage, arithmetic mean and standard 
deviation

B. Analytical Statistics:

i. Independent Samples T-Test

ii. One-Way ANOVA

iii. Standard Multiple Regression Analysis

iv. Simple Regression Analysis

Presentation and analysis of field study data

\section{First: Gender:}

The answers of the respondents were presented in table $(1 / 5)$

Table (1/5) Frequencies and Percentages for Gender variable

\begin{tabular}{|c|c|c|}
\hline Gender & Frequency & Percentage \\
\hline Male & 141 & $58.7 \%$ \\
\hline Female & 99 & $41.3 \%$ \\
\hline Total & $\mathbf{2 4 0}$ & $\mathbf{1 0 0 . 0 \%}$ \\
\hline
\end{tabular}

Table (5/1) shows that the percentage of males is the highest in the sample of the study. The total number of males which is (141) represents $58.7 \%$ of the study sample. But females their percentage equals $41.3 \%$. The reason for the superiority of the males over females is due to the fact that males have greater chances for working as indicated in Figure (1/5).

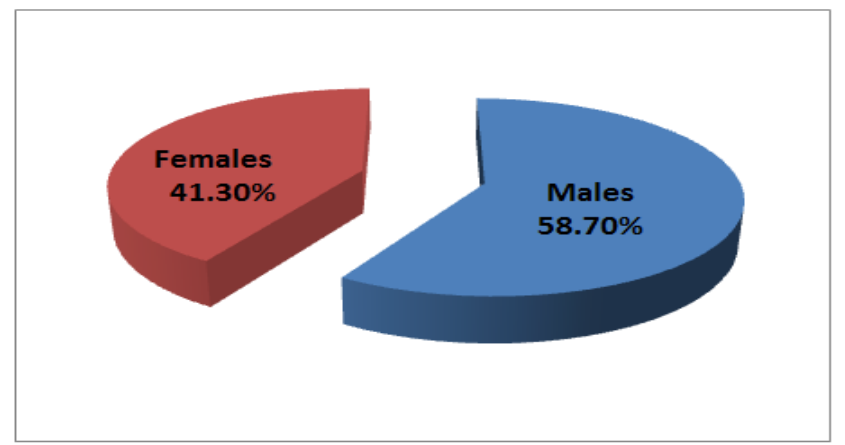

Figure 1/5 Frequencies and Percentages for Gender Variable

\section{Second: Years of Experience:}

The answers of the respondents were presented in table $(2 / 5)$

Table (2/5) Frequencies and Percentages for Years of Experience variable:

\begin{tabular}{|l|r|l|}
\hline Years of Experience & Frequency & Percentage \\
\hline Less than 5 years & 40 & $16.7 \%$ \\
\hline $\begin{array}{l}\text { From 5 to less than 10 } \\
\text { years }\end{array}$ & 140 & $58.3 \%$ \\
\hline $\begin{array}{l}\text { From 10 to less than 15 } \\
\text { years }\end{array}$ & 20 & $8.3 \%$ \\
\hline $\begin{array}{l}\text { From 15 to less than 20 } \\
\text { years }\end{array}$ & 23 & $9.6 \%$ \\
\hline 20 years or more & 17 & $7.1 \%$ \\
\hline Total & $\mathbf{2 4 0}$ & $\mathbf{1 0 0 . 0 \%}$ \\
\hline
\end{tabular}

The data of Table (5/2) show that those aged 5 to 10 years reached $58.3 \%$, while the lowest percentage was those with experience (20 years or more) with $7.1 \%$ as demonstrated by Figure (5/2).

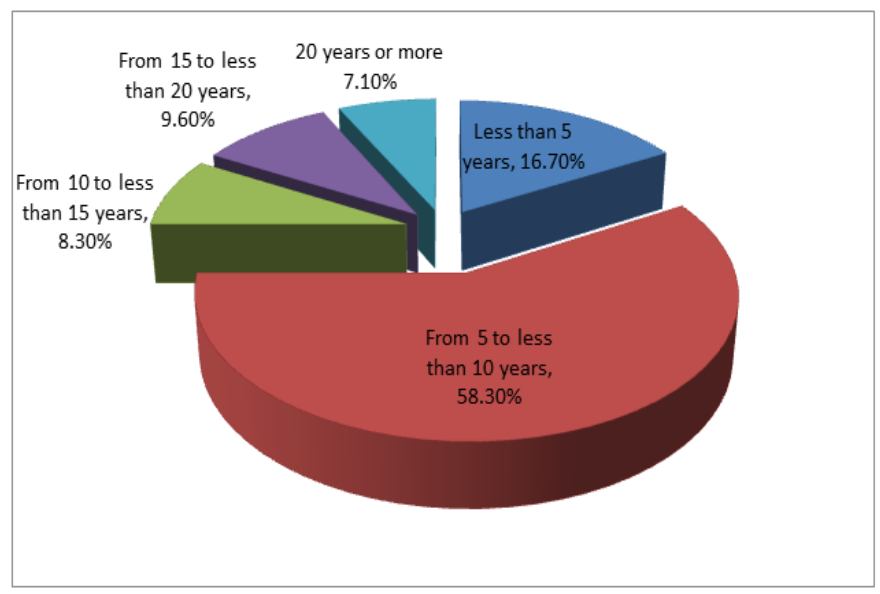

Figure 2/5 Frequencies and Percentages of Number of Years Variable

Third: Age

The answers of the respondents were presented in table $(3 / 5)$

Table (3/5) Frequencies and Percentages for Age variable:

\begin{tabular}{|l|r|l|}
\hline Age & Frequency & $\begin{array}{l}\text { Percentag } \\
\text { e }\end{array}$ \\
\hline Less than 29 years old & 42 & $17.5 \%$ \\
\hline From 29 to 39 years & 120 & $50.0 \%$ \\
\hline From 40 to 49 years old & 60 & $25.0 \%$ \\
\hline From 50 to 59 years & 11 & $4.5 \%$ \\
\hline More than 59 & 7 & $3.0 \%$ \\
\hline Total & $\mathbf{2 4 0}$ & $\mathbf{1 0 0 . 0 \%}$ \\
\hline
\end{tabular}

Table (3/5) shows that those aged 29-39 years have the highest percentage $(50.0 \%)$, while the lowest percentage was for persons aged more than 59 with a percentage of $(3.0 \%)$; as demonstrated by figure $(5 / 3)$.

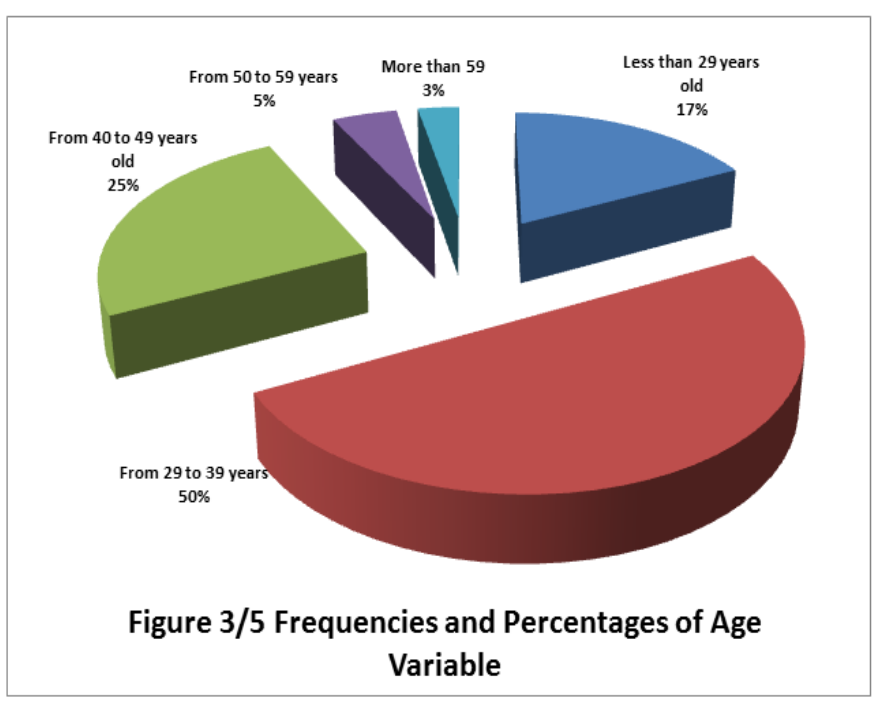


Fourth: Scientific Qualification

The answers of the respondents were presented in table (4/5)

Table (4/5) Frequencies and Percentages for Scientific Qualification variable:

\begin{tabular}{|l|r|l|}
\hline Scientific Qualification & Frequency & $\begin{array}{l}\text { Percentag } \\
\text { e }\end{array}$ \\
\hline Diploma or less & 81 & $33.8 \%$ \\
\hline Bachelor & 120 & $50.0 \%$ \\
\hline Master & 30 & $12.5 .0 \%$ \\
\hline PhD & 9 & $3.7 \%$ \\
\hline Total & $\mathbf{2 4 0}$ & $\mathbf{1 0 0 . 0 \%}$ \\
\hline
\end{tabular}

Table (4/5) shows that those with Bachelor degree have the highest percentage $(50.0 \%)$, while the lowest percentage was for persons who have $\mathrm{PhD}$ degree with a percentage of $(3.0 \%)$; as demonstrated by figure (4/5).

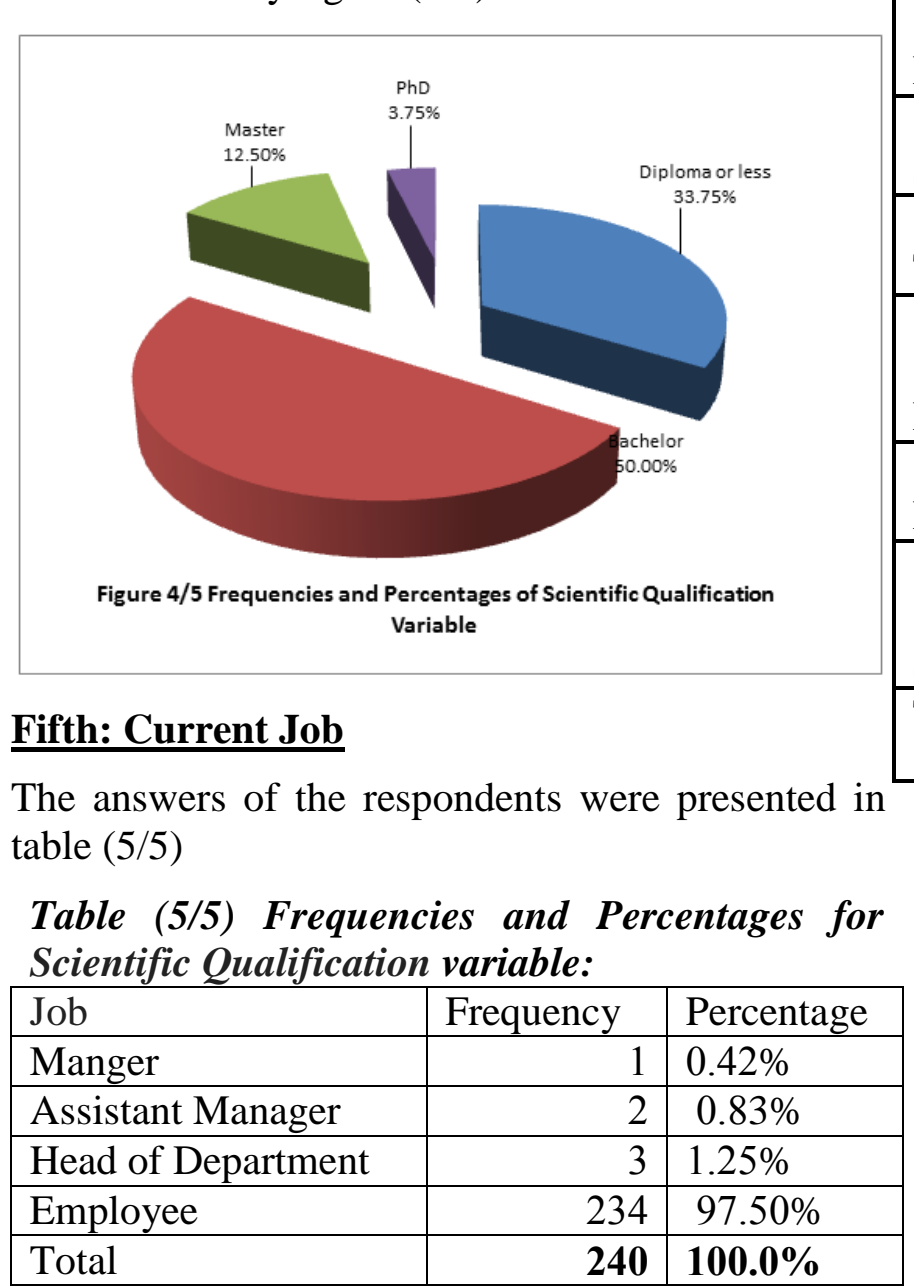

Table (5/5) shows that those are just employees have the highest percentage $(97.6 \%)$, while the lowest percentage was for persons are managers with a percentage of $(0.4 \%)$; as demonstrated by figure $(5 / 5)$.

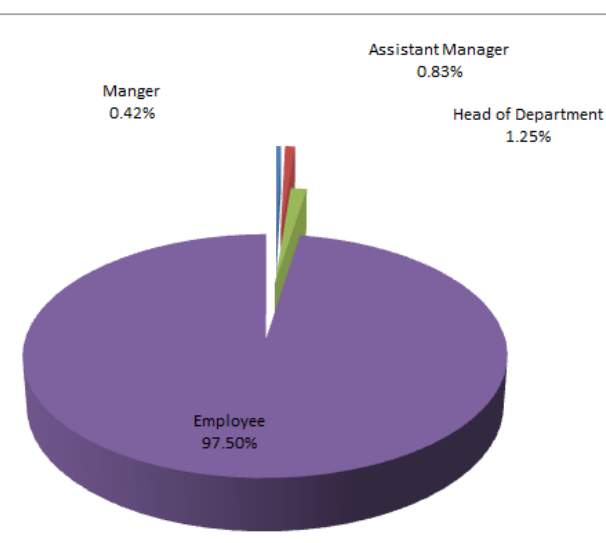

Figure 5/5 Frequencies and Percentages of Current JobVariable

Table (6/5) Numbers and sum of items the measure the fields of the study:

\begin{tabular}{|c|c|c|c|}
\hline $\begin{array}{l}\text { Rank of the } \\
\text { field }\end{array}$ & $\begin{array}{l}\text { Fields of the } \\
\text { study }\end{array}$ & Sum & $\begin{array}{l}\text { Numbers of } \\
\text { Items }\end{array}$ \\
\hline First Field & $\begin{array}{l}\text { Changing } \\
\text { path }\end{array}$ & 5 & 1، 2، 3، 5 \\
\hline Second Field & $\begin{array}{l}\text { Reserve } \\
\text { Mobilization }\end{array}$ & 4 & 6، \\
\hline Third Field & Group work & 7 & 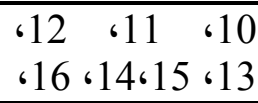 \\
\hline Fourth Field & $\begin{array}{l}\text { Crisis } \\
\text { Fragmentatio } \\
\mathrm{n}\end{array}$ & 4 & ، 17، 18، 19، 20 \\
\hline Fifth Field & $\begin{array}{l}\text { Crisis } \\
\text { Containment }\end{array}$ & 4 & $\begin{array}{lll}23 & 62 & 621 \\
& & 64 \\
\end{array}$ \\
\hline Sixth Field & $\begin{array}{l}\text { Crisis } \\
\text { Exhausting }\end{array}$ & 6 & 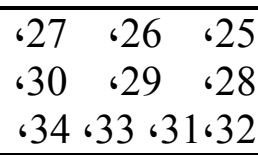 \\
\hline \multicolumn{3}{|c|}{ Total Sum of Items of the tool } & \\
\hline
\end{tabular}

\section{Validity of the study tool:}

The questionnaire was presented to a group of specialized referees in Jordanian universities who are (8) professors in order to express their opinion. Their comments were taken for amendment to the wording of some items in terms of construction and language.

\section{Reliability of the study tool:}

Pearson Correlation coefficient was used to calculate stability (Test-retest reliability) and also Cronbach's alpha to calculate Internal Consistency reliability. 
Table (7/5) stability and Internal consistency coefficients of the study tool and its axes:

\begin{tabular}{|l|l|r|r|r|}
\hline $\begin{array}{l}\text { N } \\
\text { o. }\end{array}$ & Field of the study & Sum & $\begin{array}{l}\text { Stabi } \\
\text { lity }\end{array}$ & $\begin{array}{l}\text { Internal } \\
\text { consistenc } \\
\text { y }\end{array}$ \\
\hline 1 & $\begin{array}{l}\text { First Field } \\
\text { :Changing path }\end{array}$ & 5 & 0.82 & 0.93 \\
\hline 2 & $\begin{array}{l}\text { Second Field: } \\
\text { Reserve } \\
\text { Mobilization }\end{array}$ & 4 & 0.81 & 0.92 \\
\hline 3 & $\begin{array}{l}\text { Third Field: } \\
\text { Group work }\end{array}$ & 7 & 0.82 & 0.87 \\
\hline 4 & $\begin{array}{l}\text { Fourth Field: } \\
\text { Crisis } \\
\text { Fragmentation }\end{array}$ & 4 & 0.83 & 0.90 \\
\hline 5 & $\begin{array}{l}\text { Fifth Field: Crisis } \\
\text { Containment }\end{array}$ & 4 & 0.87 & 0.91 \\
\hline 6 & $\begin{array}{l}\text { Sixth Field: Crisis } \\
\text { Exhausting }\end{array}$ & 6 & 0.80 & 0.85 \\
\hline $\begin{array}{l}\text { Total Sum of Items of } \\
\text { the tool }\end{array}$ & 34 & $\mathbf{0 . 8 2}$ & $\mathbf{0 . 8 9 6 6}$ \\
\hline
\end{tabular}

It is obvious from table (7/5) that the stability and internal consistency coefficients of the study tool and its fields are sufficient indicators for the purposes of the study to the study tool in its final application as it was appeared in the previous studies as criterion of stability, Miller (1998) indicated that if the stability coefficient is greater than 0.60 it is considered a high stability coefficient, so this has high stability coefficients.

\section{Analysis of the study data:}

This chapter deals with the results obtained by analyzing the statistical data collected from the questionnaire that was addressed to a group of employees of Arab Potash Company. The questionnaire was based on the "Likert" scale. The questionnaire included the degree of approval of each item divided into (5) categories, where these responses were entered on the computer as shown in Table (8/5).

\begin{tabular}{|l|l|}
\hline \multicolumn{2}{|l|}{ Table (8/5) Degree of response and its symbol } \\
\hline Degree of response & Symbol \\
\hline Strongly agree & 5 \\
\hline Agree & 4 \\
\hline Neutral & 3 \\
\hline Disagree & 2 \\
\hline Strongly disagree & 1 \\
\hline
\end{tabular}

Based on the symbols given to the responses, arithmetic averages of the responses were calculated in order to judge the degree of approval with each item in the questionnaire. The values of the arithmetic averages were calculated to judge the degree of approval as demonstrated by table (8/5).

Table (8/5) Arithmetic Averages and degree of approval:

\begin{tabular}{|l|l|}
\hline Arithmetic Average & Degree of approval \\
\hline $1-2.33$ & Low \\
\hline $2.34-3.67$ & Moderate \\
\hline $3.68-5$ & High \\
\hline
\end{tabular}

\section{Discussion:}

First Field: Changing Path

Table (9/5) represents arithmetic average, standard deviation and degree of approval of each item of this dimension.

Table (9/5) Arithmetic Average, Standard deviation and degree of approval of each individual in the sample toward the dimension (changing path)

\begin{tabular}{|l|l|r|r|r|l|}
\hline No. & Item & $\begin{array}{l}\text { Arithmetic } \\
\text { average }\end{array}$ & S.D. & Rank & $\begin{array}{l}\text { Degree } \\
\text { Approval }\end{array}$ \\
\hline 1 & $\begin{array}{l}\text { The administration of Arab Potash } \\
\text { Company deals with crises based on the } \\
\text { appropriate options for its strength. }\end{array}$ & 4.1325 & .88449 & High \\
\hline 2 & $\begin{array}{l}\text { Previous economic crises have had an } \\
\text { impact on the company business } \\
\text { performance }\end{array}$ & 3.9518 & .91325 & High \\
\hline 3 & $\begin{array}{l}\text { The administration of Arab Potash } \\
\text { Company is trying to draw the attention of } \\
\text { the public to a subject different from the } \\
\text { subject of the crisis is often positive. }\end{array}$ & 3.8313 & 1.00688 & High \\
\hline 4 & $\begin{array}{l}\text { Changing path strategy has a positive } \\
\text { impact of the expected performance of the }\end{array}$ & 3.7223 & 1.1188 & $\mathbf{5}$ & High \\
\hline \hline
\end{tabular}




\begin{tabular}{|l|l|r|r|r|l|}
\hline 5 & company & & & & \\
\hline 5 & $\begin{array}{l}\text { The administration of Arab Potash } \\
\text { Company utilizes changing path strategy } \\
\text { when it faces unclear aspect crises }\end{array}$ & 4.0181 & .95011 & $\mathbf{2}$ & High \\
\hline & Total field & $\mathbf{3 . 9 3 1 2}$ & $\mathbf{0 . 9 7 4 7 0}$ & & High \\
\hline
\end{tabular}

The arithmetic averages of the answers of the respondents related to the first field (changing path) has ranged $(4.1325-3.7223)$. Table (9/5) indicates that the general arithmetic average of respondents' answers to the first field (changing path) was (3.9312), with a "high" degree and that the standard deviation was 0.97470 . Item (1) has got the highest mean (4.1325) with a standard deviation of (.88449) stating that " The management of the company deals with crises based on the appropriate options for its strength ", followed by the item (5) stating that " The management of the company utilizes changing path strategy when it faces unclear aspect

.Table (10/5) Arithmetic Average, Standard deviation and degree of approval of each individual in the sample toward the dimension (Reserve Mobilization)

\begin{tabular}{|l|l|r|r|r|l|}
\hline No. & Item & $\begin{array}{l}\text { Arithmetic } \\
\text { average }\end{array}$ & S.D. & Rank & $\begin{array}{l}\text { Degree of } \\
\text { Approval }\end{array}$ \\
\hline 6 & $\begin{array}{l}\text { There is aware of the company that there } \\
\text { must be a safety limit to the inventory of } \\
\text { raw materials. }\end{array}$ & 3.8916 & 1.06187 & High \\
\hline 7 & $\begin{array}{l}\text { The company usually provides a sufficient } \\
\text { stock of products }\end{array}$ & 3.8978 & 1.03062 & 3 & High \\
\hline 8 & $\begin{array}{l}\text { The administration of Arab Potash } \\
\text { Company usually provides a stock of cash } \\
\text { to deal with crises. }\end{array}$ & 3.9398 & .98288 & High \\
\hline 9 & $\begin{array}{l}\text { The administration of Arab Potash } \\
\text { Company believes that the reserve } \\
\text { mobilization strategy is necessary to deal } \\
\text { with crises. }\end{array}$ & 3.8976 & 1.01879 & High \\
\hline
\end{tabular}

The arithmetic averages of the answers of the respondents related to the second field (Reserve Mobilization) has ranged (3.9398 - 3.8916). Table $(10 / 5)$ indicates that the general arithmetic average of respondents' answers to the second field (Reserve Mobilization) was (3.9065), with a "high" degree and that the standard deviation was 0.97470. Item (8) has got the highest mean (3.9398) with a standard deviation of (.98288) stating that " The company's management usually provides a stock of cash to deal with crises ", followed by the item (9) stating that " The company's management believes that the reserve mobilization strategy is necessary to crises," with (4.0181) arithmetic average and 0.95011 standard deviation.

But item (4) which states that "Changing path strategy has a positive impact of the expected performance of the company," has got the lowest arithmetic average of 3.7223 with a standard deviation of 1.1188 .

\section{Second Field: Reserve Mobilization:}

Table (10/5) represents arithmetic average, standard deviation and degree of approval of each item of this dimension

Table (11/5) Arithmetic Average, Standard deviation and degree of approval of each individual in the sample toward the dimension (Group work)

\begin{tabular}{|l|l|l|l|l|l|}
\hline No. & Item & Arithmetic & S.D. & Rank & Degree of \\
\hline \hline
\end{tabular}




\begin{tabular}{|c|c|c|c|c|c|}
\hline & & average & & & Approval \\
\hline 10 & $\begin{array}{l}\text { The company is working on training } \\
\text { employees in the methods of teamwork. }\end{array}$ & 3.5663 & 1.05822 & 7 & Moderate \\
\hline 11 & $\begin{array}{l}\text { The administration of Arab Potash } \\
\text { Company encourages and stimulates } \\
\text { teamwork }\end{array}$ & 3.7048 & 1.14027 & 6 & High \\
\hline 12 & $\begin{array}{l}\text { The administration of Arab Potash } \\
\text { Company encourages all employees to } \\
\text { work as a team in order to achieve the } \\
\text { right quality of work. }\end{array}$ & 3.9880 & .97848 & 2 & High \\
\hline 13 & $\begin{array}{l}\text { The formation of the task force improves } \\
\text { the efficiency of the staff of the potash } \\
\text { company }\end{array}$ & 3.9940 & 99390 & 1 & High \\
\hline 14 & $\begin{array}{l}\text { The administration of Arab Potash } \\
\text { Company uses teams as a management } \\
\text { method to solve the problems they face }\end{array}$ & 3.8253 & .97214 & 3 & High \\
\hline 15 & $\begin{array}{l}\text { The administration of Arab Potash } \\
\text { Company successfully uses self-managed } \\
\text { teams }\end{array}$ & 3.8121 & .81541 & 4 & High \\
\hline 16 & $\begin{array}{l}\text { The administration of Arab Potash } \\
\text { Company organizes working groups that } \\
\text { meet regularly to discuss work problems } \\
\text { and complete the necessary procedures }\end{array}$ & 3.7414 & .97121 & 5 & High \\
\hline & Total field & 3.80455 & 0.98994 & & High \\
\hline
\end{tabular}

The arithmetic averages of the answers of the respondents related to the third field (Group work) has ranged $(3.9940-3.5663)$. Table $(11 / 5)$ indicates that the general arithmetic average of respondents' answers to the third field (Group work) was (3.80455), with a "high" degree and that the standard deviation was 0.98994 . Item (13) has got the highest mean (3.9940) with a standard deviation of (.99390) stating that " The formation of the task force improves the efficiency of the staff of the potash company," followed by the item (12) stating that " The administration of Arab Potash Company encourages all employees to work as a team in order to achieve the right quality of work," with (3.9880) arithmetic average and .97848 standard deviation.

But item (10) which states that "The Company is working on training employees in the methods of teamwork," has got the lowest arithmetic average of 3.7048 with a standard deviation of 1.05822

\section{Fourth Field: Crisis Fragmentation}

Table (12/5) represents arithmetic average, standard deviation and degree of approval of each item of this dimension.

Table (12/5) Arithmetic Average, Standard deviation and degree of approval of each individual in the sample toward the dimension (Crisis_Fragmentation)

\begin{tabular}{|l|l|r|r|r|l|}
\hline No. & Item & $\begin{array}{l}\text { Arithmetic } \\
\text { average }\end{array}$ & S.D. & $\begin{array}{l}\text { Ran } \\
\mathrm{k}\end{array}$ & $\begin{array}{l}\text { Degree of } \\
\text { Approval }\end{array}$ \\
\hline 17 & $\begin{array}{l}\text { The administration of Arab Potash Company has } \\
\text { sufficient information about the nature of the crisis it } \\
\text { faces. }\end{array}$ & $\mathbf{1}$ & High \\
\hline 18 & $\begin{array}{l}\text { The administration of Arab Potash Company } \\
\text { conducts the necessary studies to identify the } \\
\text { conflicting interests that cause the crisis. }\end{array}$ & 3.9819 & 1.02380 & $\mathbf{2}$ & High \\
\hline 19 & $\begin{array}{l}\text { The administration of Arab Potash Company relies } \\
\text { on specialists to break up and to dissolve the crisis. }\end{array}$ & 3.5723 & 1.10819 & $\mathbf{4}$ & Moderate \\
\hline 20 & $\begin{array}{l}\text { The company is usually able to fragment and break } \\
\text { down the crisis successfully. }\end{array}$ & 3.8193 & 1.03449 & $\mathbf{3}$ & High \\
\hline
\end{tabular}


The arithmetic averages of the answers of the respondents related to the fourth field (Crisis Fragmentation) has ranged (4.1024-3.5723). Table $(12 / 5)$ indicates that the general arithmetic average of respondents' answers to the fourth field (Crisis Fragmentation) was (3.8689), with a "high" degree and that the standard deviation was 1.0521. Item (17) has got the highest mean (4.1024) with a standard deviation of (1.04231) stating that "The administration of Arab Potash Company has sufficient information about the nature of the crisis it faces," followed by the item (18) stating that "The administration of Arab Potash Company conducts the necessary studies to identify the conflicting interests that cause the crisis," with (3.9819) arithmetic average and 1.02380 standard deviation.

But item (19) which states that "The Company is working on training employees in the methods of teamwork," has got the lowest arithmetic average of 3.5723 with a standard deviation of 1.10819 .

\section{Fifth Field: Crisis Containment}

Table (13/5) represents arithmetic average, standard deviation and degree of approval of each item of this dimension.

\section{Table (13/5) Arithmetic Average, Standard deviation and degree of approval of each individual in the} sample toward the dimension (Crisis_Containment)

\begin{tabular}{|l|l|r|r|r|l|}
\hline No. & Item & $\begin{array}{l}\text { Arithmetic } \\
\text { average }\end{array}$ & S.D. & $\begin{array}{l}\text { Ran } \\
\mathrm{k}\end{array}$ & $\begin{array}{l}\text { Degree of } \\
\text { Approval }\end{array}$ \\
\hline 21 & $\begin{array}{l}\text { The administration of Arab Potash Company } \\
\text { adopts specialized teams from within to contain the } \\
\text { crisis. }\end{array}$ & 4.1221 & 1.00031 & $\mathbf{1}$ & High \\
\hline 22 & $\begin{array}{l}\text { Over the past years, the company has successfully } \\
\text { managed to contain crises. }\end{array}$ & 3.9718 & 1.01180 & $\mathbf{2}$ & High \\
\hline 23 & $\begin{array}{l}\text { The administration of Arab Potash Company is } \\
\text { negotiating with the cause of the crisis to contain it. }\end{array}$ & 3.5214 & 1.44419 & $\mathbf{4}$ & Moderate \\
\hline 24 & $\begin{array}{l}\text { The staff is doing the required efforts to help to } \\
\text { contain the crisis. }\end{array}$ & 3.8581 & 1.05414 & $\mathbf{3}$ & High \\
\hline & Total field & $\mathbf{3 . 8 6 8 9}$ & $\mathbf{1 . 0 5 2 1}$ & & High \\
\hline
\end{tabular}

The arithmetic averages of the answers of the respondents related to the fifth field (Crisis Containment) has ranged (4.1024 - 3.5723). Table $(12 / 5)$ indicates that the general arithmetic average of respondents' answers to the fifth field (Crisis Containment) was (3.8689), with a "high" degree and that the standard deviation was 1.0521. Item (21) has got the highest mean (4.1221) with a standard deviation of (1.00031) stating that "The administration of Arab Potash Company adopts specialized teams from within to contain the crisis," followed by the item (22) stating that "Over the past years, the company has successfully managed to contain crises," with (3.9718) arithmetic average and 1.01180 standard deviation.

But item (19) which states that "The Company is working on training employees in the methods of teamwork," has got the lowest arithmetic average of 3.5214 with a standard deviation of 1.44419 .

\section{Sixth Field: Crisis Exhausting}

Table (14/5) represents arithmetic average, standard deviation and degree of approval of each item of this dimension.

\section{Table (14/5) Arithmetic Average, Standard deviation and degree of approval of each individual in the} sample toward the dimension (Crisis_Exhausting)

\begin{tabular}{|l|l|l|l|l|l|}
\hline No & Item & $\begin{array}{l}\text { Arithmetic } \\
\text { average }\end{array}$ & S.D. & $\begin{array}{l}\text { Ran } \\
\mathrm{k}\end{array}$ & $\begin{array}{l}\text { Degree of } \\
\text { Approval }\end{array}$ \\
\hline 25 & $\begin{array}{l}\text { The administration of Arab Potash Company is able } \\
\text { to analyze the content and content of the crisis and } \\
\text { deal with it. }\end{array}$ & 4.2141 & 1.98131 & $\mathbf{1}$ & High \\
\hline 26 & $\begin{array}{l}\text { The administration of Arab Potash Company } \\
\text { recognizes the existence of the crisis in principle to } \\
\text { ensure the evacuating and treating it. }\end{array}$ & 3.8894 & 1.07780 & $\mathbf{2}$ & High \\
\hline 27 & The company is establishing temporary alliances & 3.6251 & 1.49919 & $\mathbf{4}$ & Moderate \\
\hline
\end{tabular}




\begin{tabular}{|l|l|r|r|r|l|}
\hline & with the crisis-causing elements to address them. & & & & \\
\hline 28 & $\begin{array}{l}\text { The company believes that Crisis Exhausting } \\
\text { strategy is an appropriate solution to the crisis. }\end{array}$ & 3.7514 & 1.75114 & $\mathbf{3}$ & High \\
\hline & Total field & $\mathbf{3 . 8 7 0 0}$ & $\mathbf{1 . 5 7 7 3 6}$ & & High \\
\hline
\end{tabular}

The arithmetic averages of the answers of the respondents related to the sixth field (Crisis Exhausting) has ranged $(4.2141-3.6251)$. Table $(14 / 5)$ indicates that the general arithmetic average of respondents' answers to the sixth field (Crisis Exhausting) was (3.8700), with a "high" degree and that the standard deviation was 1.57736. Item (25) has got the highest mean (4.2141) with a standard deviation of (1.98131) stating that "The administration of Arab Potash Company is able to analyze the content and content of the crisis and deal with it," followed by the item (26) stating that " The administration of Arab Potash Company recognizes the existence of the crisis in principle toensure the evacuating and treating it," with (3.8894) arithmetic average and 1.07780 standard deviation.

But item (27) which states that "The Company is establishing temporary alliances with the crisiscausing elements to address them," has got the lowest arithmetic average of 3.6251 with a standard deviation of 1.07780 .

\section{Seventh Field: Employee Performance}

Table (15/5) represents arithmetic average, standard deviation and degree of approval of each item of this dimension

\section{.Table (15/5) Arithmetic Average, Standard deviation and degree of approval of each individual in the sample toward the dimension (Employee Performance)}

\begin{tabular}{|l|l|r|r|r|l|}
\hline No. & Item & $\begin{array}{l}\text { Arithmetic } \\
\text { average }\end{array}$ & S.D. & $\begin{array}{l}\text { Ran } \\
\mathrm{k}\end{array}$ & $\begin{array}{l}\text { Degree of } \\
\text { Approval }\end{array}$ \\
\hline 29 & $\begin{array}{l}\text { Commitment to quality provides precision in the work } \\
\text { done. }\end{array}$ & 4.1687 & 1.00688 & $\mathbf{1}$ & High \\
\hline 30 & $\begin{array}{l}\text { Managing crises wisely is, of course, reflected in } \\
\text { improving productivity. }\end{array}$ & 4.0422 & .92999 & $\mathbf{5}$ & High \\
\hline 31 & $\begin{array}{l}\text { The company's ability to manage the crisis is reflected } \\
\text { positively on the performance of employees. }\end{array}$ & 4.0723 & .91165 & $\mathbf{3}$ & High \\
\hline 32 & $\begin{array}{l}\text { The management of the crisis in a rational manner } \\
\text { reflects positively on the satisfaction of the workers, } \\
\text { as the greater the satisfaction of workers, the } \\
\text { productivity increases. }\end{array}$ & 4.0181 & 1.01786 & $\mathbf{6}$ & High \\
\hline 33 & $\begin{array}{l}\text { The company's ability to manage the crisis properly } \\
\text { reflects the credibility of the company with its } \\
\text { customers }\end{array}$ & 4.0711 & 1.08190 & $\mathbf{4}$ & High \\
\hline 34 & $\begin{array}{l}\text { The company's ability to manage the crisis properly } \\
\text { reduces business errors }\end{array}$ & 4.1627 & .96172 & $\mathbf{2}$ & High \\
\hline & Total field & $\mathbf{4 . 0 8 9 1}$ & $\mathbf{0 . 9 8 5}$ & & High \\
\hline
\end{tabular}

The arithmetic averages of the answers of the respondents related to the seventh field (Employee Performance) has ranged (4.1687 - 4.0181). Table $(15 / 5)$ indicates that the general arithmetic average of respondents' answers to the seventh field (Employee Performance) was (4.0891), with a "high" degree and that the standard deviation was 0.985. Item (29) has got the highest mean (4.1687)

with a standard deviation of (1.00688) stating that "Commitment to quality provides precision in the work done," followed by the item (34) stating that "The company's ability to manage the crisis properly reduces business errors," with (4.1627) arithmetic average and .96172 standard deviation.

But item (32) which states that "The Company is establishing temporary alliances with the crisiscausing elements to address them," has got the lowest arithmetic average of 4.0181 with a standard deviation of 1.01786 .

\section{HYPOTHESES TESTING:}

The main Hypothesis $\left(\mathrm{H}_{0} 1\right)$ : there is no statistically significant impact at $(\alpha=0.05)$ of the strategy of crisis management (in terms of its dimensions) in 
improving the performance of the workers of Arab Potash Company.

From this main hypothesis, the following subhypotheses are emerged:

In order to identify the probability of accepting or rejecting this hypothesis, the researchers have used Multiple Linear Regression as demonstrated in Table (16/5).

\section{Table (16/5)}

The results of multiple Regression Analysis of the First Main Hypothesis

\begin{tabular}{|l|l|l|l|l|l|}
\hline $\begin{array}{l}\text { Calculate } \\
\text { d F }\end{array}$ & Beta & Sig. & $\mathrm{R}$ & $\mathrm{R}^{2}$ & $\begin{array}{l}\text { Decisi } \\
\text { on }\end{array}$ \\
\hline 109.555 & $\begin{array}{l}0.54 \\
4\end{array}$ & $\begin{array}{l}* 0.00 \\
2\end{array}$ & $\begin{array}{l}0.33 \\
3\end{array}$ & $\begin{array}{l}0.11 \\
0\end{array}$ & Reject \\
\hline
\end{tabular}

statistically significant at $\alpha \leq 0.05$

The results shown in table $(16 / 5)$ indicate that the significance level (0.001) which is less than (0.05) so the decision rule states to accept the alternative hypothesis if the significance level (Sig.) is less than (0.05), and to reject the null hypothesis if the significance level (Sig.) is less than (0.05). From the previous table it is obvious that Sig. is less than 0.05 so the decision rule states that there is a statistically significant impact of Crisis Management by its dimensions in improving the performance of the workers in Arab Potash Company.

First sub-hypothesis $\left(\mathrm{H}_{0} 1-1\right)$ : there is no statistically significant impact at $(\alpha=0.05)$ of Changing Path Strategy in improving the performance of the workers of Arab Potash Company.

In order to identify the probability of accepting or rejecting this hypothesis, the researchers have used Simple Linear Regression as demonstrated in Table (17/5).

\section{Table (17/5)}

The results of Simple Linear Regression Analysis of the First Sub-Hypothesis

\begin{tabular}{|l|l|l|l|l|l|}
\hline $\begin{array}{l}\text { Calculate } \\
\text { d F }\end{array}$ & Beta & Sig. & $\mathrm{R}$ & $\mathrm{R}^{2}$ & $\begin{array}{l}\text { Decisi } \\
\text { on }\end{array}$ \\
\hline 291.214 & $\begin{array}{l}0.84 \\
4\end{array}$ & $\begin{array}{l}* 0.00 \\
1\end{array}$ & $\begin{array}{l}0.22 \\
2\end{array}$ & $\begin{array}{l}0.04 \\
9\end{array}$ & Reject \\
\hline
\end{tabular}

statistically significant at $\alpha \leq 0.05$

The results shown in table $(17 / 5)$ indicate that the significance level (0.002) which is less than (0.05) so the decision rule states to accept the alternative hypothesis if the significance level (Sig.) is less than (0.05), and to reject the null hypothesis if the significance level (Sig.) is less than (0.05). From the previous table it is obvious that Sig. is less than 0.05 so the decision rule states that there is a statistically significant impact of Changing Path Strategy in improving the performance of the workers of Arab Potash Company.

Second sub-hypothesis $\left(\mathrm{H}_{0} 1-2\right)$ : there is no statistically significant impact at $(\alpha=0.05)$ of Reserve Mobilization Strategy in improving the performance of the workers of Arab Potash Company.

In order to identify the probability of accepting or rejecting this hypothesis, the researchers have used Simple Linear Regression as demonstrated in Table (18/5).

\section{Table (18/5)}

The results of Simple Linear Regression Analysis of the Second Sub-Hypothesis

\begin{tabular}{|l|l|l|l|l|l|}
\hline $\begin{array}{l}\text { Calculate } \\
\text { d F }\end{array}$ & Beta & Sig. & R & $\mathrm{R}^{2}$ & $\begin{array}{l}\text { Decisi } \\
\text { on }\end{array}$ \\
\hline 150.027 & $\begin{array}{l}0.64 \\
1\end{array}$ & $\begin{array}{l}* 0.00 \\
2\end{array}$ & $\begin{array}{l}0.64 \\
1\end{array}$ & $\begin{array}{l}0.41 \\
1\end{array}$ & Reject \\
\hline
\end{tabular}

statistically significant at $\alpha \leq 0.05$

The results shown in table (18/5) indicate that the significance level (0.002) which is less than (0.05) so the decision rule states to accept the alternative hypothesis if the significance level (Sig.) is less than (0.05), and to reject the null hypothesis if the significance level (Sig.) is less than (0.05). From the previous table it is obvious that Sig. is less than 0.05 so the decision rule states that there is a statistically significant impact of Reserve Mobilization Strategy in improving the performance of the workers of Arab Potash Company.

Third sub-hypothesis $\left(\mathrm{H}_{0} 1-3\right)$ : there is no statistically significant impact at $(\alpha=0.05)$ of Group work Strategy in improving the performance of the workers of Arab Potash Company.

In order to identify the probability of accepting or rejecting this hypothesis, the researchers have used Simple Linear Regression as demonstrated in Table (19/5).

\section{Table (19/5)}

The results of Simple Linear Regression Analysis of the Third Sub-Hypothesis

\begin{tabular}{|l|l|l|l|l|l|}
\hline $\begin{array}{l}\text { Calculate } \\
\text { d F }\end{array}$ & Beta & Sig. & R & $\mathrm{R}^{2}$ & $\begin{array}{l}\text { Decisi } \\
\text { on }\end{array}$ \\
\hline 140.896 & $\begin{array}{l}0.68 \\
0\end{array}$ & $\begin{array}{l}* 0.00 \\
4\end{array}$ & $\begin{array}{l}0.51 \\
8\end{array}$ & $\begin{array}{l}0.26 \\
8\end{array}$ & Reject \\
\hline
\end{tabular}

statistically significant at $\alpha \leq 0.05$

The results shown in table (19/5) indicate that the significance level (0.002) which is less than (0.05) so the decision rule states to accept the alternative hypothesis if the significance level (Sig.) is less 
than (0.05), and to reject the null hypothesis if the significance level (Sig.) is less than (0.05). From the previous table it is obvious that Sig. is less than 0.05 so the decision rule states that there is a statistically significant impact of Group work Strategy in improving the performance of the workers of Arab Potash Company.

Fourth sub-hypothesis $\left(\mathrm{H}_{0} 1-4\right)$ : there is no statistically significant impact at $(\alpha=0.05)$ of Crisis Fragmentation Strategy in improving the performance of the workers of Arab Potash Company.

In order to identify the probability of accepting or rejecting this hypothesis, the researchers have used Simple Linear Regression as demonstrated in Table (20/5).

\section{Table (20/5)}

The results of Simple Linear Regression Analysis of the Fourth Sub-Hypothesis

\begin{tabular}{|l|l|l|l|l|l|}
\hline $\begin{array}{l}\text { Calculate } \\
\text { d F }\end{array}$ & Beta & Sig. & $\mathrm{R}$ & $\mathrm{R}^{2}$ & $\begin{array}{l}\text { Decisi } \\
\text { on }\end{array}$ \\
\hline 144.637 & $\begin{array}{l}0.54 \\
1\end{array}$ & $\begin{array}{l}* 0.00 \\
0\end{array}$ & $\begin{array}{l}0.67 \\
3\end{array}$ & $\begin{array}{l}0.45 \\
2\end{array}$ & Reject \\
\hline
\end{tabular}

statistically significant at $\alpha \leq 0.05$

The results shown in table (20/5) indicate that the significance level (0.002) which is less than (0.05) so the decision rule states to accept the alternative hypothesis if the significance level (Sig.) is less than (0.05), and to reject the null hypothesis if the significance level (Sig.) is less than (0.05). From the previous table it is obvious that Sig. is less than 0.05 so the decision rule states that there is a statistically significant impact of Crisis Fragmentation Strategy in improving the performance of the workers of Arab Potash Company.

Fifth sub-hypothesis $\left(\mathrm{H}_{0} 1-5\right)$ : there is no statistically significant impact at $(\alpha=0.05)$ of Crisis Containment Strategy in improving the performance of the workers of Arab Potash Company.

In order to identify the probability of accepting or rejecting this hypothesis, the researchers have used Simple Linear Regression as demonstrated in Table (21/5).

\section{Table (21/5)}

The results of Simple Linear Regression Analysis of the Fourth Sub-ypothesis

\begin{tabular}{|l|l|l|l|l|l|}
\hline $\begin{array}{l}\text { Calculate } \\
\text { d F }\end{array}$ & Beta & Sig. & R & $\mathrm{R}^{2}$ & $\begin{array}{l}\text { Decisio } \\
\mathrm{n}\end{array}$ \\
\hline 144.417 & $\begin{array}{l}0.67 \\
3\end{array}$ & $\begin{array}{l}* 0.02 \\
0\end{array}$ & $\begin{array}{l}0.67 \\
3\end{array}$ & $\begin{array}{l}0.45 \\
2\end{array}$ & Reject \\
\hline
\end{tabular}

statistically significant at $\alpha \leq 0.05$

The results shown in table $(21 / 5)$ indicate that the significance level (0.002) which is less than (0.05) so the decision rule states to accept the alternative hypothesis if the significance level (Sig.) is less than (0.05), and to reject the null hypothesis if the significance level (Sig.) is less than (0.05). From the previous table it is obvious that Sig. is less than 0.05 so the decision rule states that there is a statistically significant impact of Crisis Containment Strategy in improving the performance of the workers of Arab Potash Company.

Sixth sub-hypothesis $\left(\mathrm{H}_{0} 1-6\right)$ : there is no statistically significant impact at $(\alpha=0.05)$ of Crisis Exhausting Strategy in improving the performance of the workers of Arab Potash Company.

In order to identify the probability of accepting or rejecting this hypothesis, the researchers have used Simple Linear Regression as demonstrated in Table (22/5).

\section{Table (22/5)}

The results of Simple Linear Regression Analysis of the Fourth Sub-Hypothesis

\begin{tabular}{|l|l|l|l|l|l|}
\hline $\begin{array}{l}\text { Calculate } \\
\text { d F }\end{array}$ & Beta & Sig. & R & $\mathrm{R}^{2}$ & $\begin{array}{l}\text { Decisio } \\
\mathrm{n}\end{array}$ \\
\hline 144.514 & $\begin{array}{l}0.65 \\
1\end{array}$ & $\begin{array}{l}* 0.00 \\
0\end{array}$ & $\begin{array}{l}0.22 \\
2\end{array}$ & $\begin{array}{l}0.04 \\
9\end{array}$ & Reject \\
\hline
\end{tabular}

statistically significant at $\alpha \leq 0.05$

The results shown in table $(22 / 5)$ indicate that the significance level (0.002) which is less than (0.05) so the decision rule states to accept the alternative hypothesis if the significance level (Sig.) is less than (0.05), and to reject the null hypothesis if the significance level (Sig.) is less than (0.05). From the previous table it is obvious that Sig. is less than 0.05 so the decision rule states that there is a statistically significant impact of Crisis Exhausting Strategy in improving the performance of the workers of Arab Potash Company.

\section{RESULTS:}

The results of the analysis and hypotheses testing and the questions of the study could be summarized as follows:

The main Hypothesis $\left(\mathbf{H}_{\mathbf{0}} \mathbf{1}\right)$ : there is no statistically significant impact at $(\alpha=0.05)$ of the strategy of crisis management (in terms of its dimensions) in improving the performance of the workers of Arab Potash Company.

Table (16/5) indicates the significance level equals (0.001) which is less than (0.05), so the decision rule states to reject the null hypothesis and to accept the alternative hypothesis since Sig. is less 
than 0.05 , consequently, there is a statistically significant impact at $(\alpha=0.05)$ of the strategy of crisis management (in terms of its dimensions) in improving the performance of the workers of Arab Potash Company.

First sub-hypothesis $\left(\mathbf{H}_{\mathbf{0}} \mathbf{1 - 1}\right)$ : there is no statistically significant impact at $(\alpha=0.05)$ of Changing Path Strategy in improving the performance of the workers of Arab Potash Company.

Table (17/5) indicates the significance is less than (0.05), so the decision rule states to reject the null hypothesis and to accept the alternative hypothesis since Sig. is less than 0.05 , consequently, there is a statistically significant impact at $(\alpha=0.05)$ of Changing Path Strategy in improving the performance of the workers of Arab Potash Company.

Second sub-hypothesis $\left(\mathbf{H}_{\mathbf{0}} \mathbf{1 - 2}\right)$ : there is no statistically significant impact at $(\alpha=0.05)$ of Reserve Mobilization Strategy in improving the performance of the workers of Arab Potash Company.

Table (18/5) indicates the significance is less than (0.05), so the decision rule states to reject the null hypothesis and to accept the alternative hypothesis since Sig. is less than 0.05 , consequently, there is a statistically significant impact at $(\alpha=0.05)$ of Reserve Mobilization Strategy in improving the performance of the workers of Arab Potash Company.

Third sub-hypothesis $\left(\mathrm{H}_{\mathbf{0}} \mathbf{1 - 3}\right)$ : there is no statistically significant impact at $(\alpha=0.05)$ of Group work Strategy in improving the performance of the workers of Arab Potash Company.

Table (19/5) indicates the significance is less than (0.05), so the decision rule states to reject the null hypothesis and to accept the alternative hypothesis since Sig. is less than 0.05 , consequently, there is a statistically significant impact at $(\alpha=0.05)$ of Group work Strategy in improving the performance of the workers of Arab Potash Company.

Fourth sub-hypothesis $\left(\mathbf{H}_{\mathbf{0}} \mathbf{1 - 4}\right)$ : there is no statistically significant impact at $(\alpha=0.05)$ of Crisis Fragmentation Strategy in improving the performance of the workers of Arab Potash Company.

Table (20/5) indicates the significance is less than (0.05), so the decision rule states to reject the null hypothesis and to accept the alternative hypothesis since Sig. is less than 0.05 , consequently, there is a statistically significant impact at $(\alpha=0.05)$ of Crisis Fragmentation Strategy in improving the performance of the workers of Arab Potash Company.

Fifth sub-hypothesis ( $\left.\mathbf{H}_{\mathbf{0}} \mathbf{1 - 5}\right)$ : there is no statistically significant impact at $(\alpha=0.05)$ of Crisis Containment Strategy in improving the performance of the workers of Arab Potash Company.

Table (21/5) indicates the significance is less than (0.05), so the decision rule states to reject the null hypothesis and to accept the alternative hypothesis since Sig. is less than 0.05, consequently, there is a statistically significant impact at $(\alpha=0.05)$ of Crisis Containment Strategy in improving the performance of the workers of Arab Potash Company.

Sixth sub-hypothesis $\left(\mathrm{H}_{\mathbf{0}} \mathbf{1 - 6}\right)$ : there is no statistically significant impact at $(\alpha=0.05)$ of Crisis Exhausting Strategy in improving the performance of the workers of Arab Potash Company.

Table (22/5) indicates the significance is less than (0.05), so the decision rule states to reject the null hypothesis and to accept the alternative hypothesis since Sig. is less than 0.05 , consequently, there is a statistically significant impact at $(\alpha=0.05)$ of Crisis Exhausting Strategy in improving the performance of the workers of Arab Potash Company.

\section{RECOMMENDATIONS OF THE STUDY:}

Based on the results reached by this study, the researchers recommend the followings:

1. Combine governmental and private efforts to reach appropriate solutions to mitigate the crises faced by Jordanian companies.

2. Provide a center for the preparation of leaders and managers of companies, and equip them with the necessary capabilities to deal with crises.

3. Increase interest in conducting studies and scientific research, and specialized field studies in the field of crisis management.

4. Develop successful policies and strategies that contribute to crisis management, in cooperation with large companies and institutions that have extensive experience in this field.

5. Holding courses and training programs for managers, managers and heads of corporate departments.

6. Dependence on strategic planning to avoid crises in companies.

7. The results of this study should be circulated to the Arab Potash Company and related sectors.

\section{List of sources and references}




\section{REFERENCES:}

[1] Ibrahim Ahmed (2002): Educational Crisis Management in Schools: Causes and Treatment, Arab Thought House, Cairo.

[2] Araji, Asim Hussein. "Crisis Management between (preventive and curative): Survey study in Jordanian banks." Public Administration Volume 39 First Issue April 1999. Inar Mohammed (2011): Crisis Management Strategy: Conceptual Framing according to the Islamic Perspective, Journal of Economic and Administrative Sciences, Volume (17), (64), pp. 47-63.

[3] Hamed Abdullah Rabie, The Philosophy of Israeli Propaganda (Beirut: Palestine Liberation Organization, Research Center, 1970).

[4] Hamlawi, Mohamed Rashad. Crisis Management. Abu Dhabi: The Emirates Center for Strategic Studies and Research, 1997.

[5] Al-Khashali, Shaker and Qotob, Mohi, (2007) "The Effectiveness of the Management Information System and its Impact on Crisis Management (A Field Study in Jordanian Industrial Companies)"

[6] Saifan, Ahmed and Altit, Taghreed. (2009), entitled "Strategies of Change Strategies for Confronting Crises and their Impact on Institutional Performance: A Field Study on the Jordanian Banking Sector"

[7] Abbas Rushdi al-Amari (Management of the Contemporary International Crisis), International Politics, No. (90), 1987.

[8] Abbas Rushdi Al-Amari: Crisis Management in a Changing World (Cairo, Al-Ahram Foundation, I, 1963).

[9] Abbas Rushdi Al-Amari, Contemporary International Crisis Management, International Policy Wheel (Cairo, Al-Ahram, October 90, 1987).

[10] Abdul Wahab Al-Kayali and Kamil Zuhairi, Beirut, Political Encyclopedia (The Arab Foundation for Studies and Publishing Lebanon, the year without a date).

[11] Alaa Al-Salami, (2005), Decision Support Systems, Amman: Wael Publishing House.

[12] Fadhel Zaki Mohammed, The International Crisis between Approaches and Terminology,
Um Al-Mariq Magazine (Baghdad, Umm alMarik Research Center, Issue 8-9 October 1996).

[13] Fadel Zaki Mohammed, The Rules and Customs of Managing the International Crisis in a Changing World, Umm al-Maarek Magazine (Baghdad, Umm Al-Maqar Research Center, April 6, 1996).

[14] Philip Williams: Crisis Management and Diplomacy in the Nuclear Age, Research and Information Center, translated book series (London, Martin Roberts Publications, No. 15), 1976.

[15] Mohammed Jassim Al-Dhahabi, Administrative Development, 2001, Baghdad

[16] Muhammad Aziz Abdul-Hassan Al-Bayati, United Nations and International Relations, Master's thesis, unpublished introduction to the Faculty of Political Science, University of Baghdad, March 1994. Mohamed Fahad (2012) "The Impact of Modern Crisis Management Strategies on Marketing Performance: A Field Study on Human Pharmaceutical Industrial Companies in Greater Amman"

[17] Nassif Yousef Hakki, Theory in International Relations (Beirut, Dar al-Kitab alArabi, I, 1985).

[18] Hashem Ahmed (2009) entitled "Analyzing the impact of crisis management strategies on the organizational performance of Palestinian companies.

[19] Bernstein,c.(2012): Crisis Management and Sports in the Age of Social Media: Acase Study Analysis of the Tiger Woods Scandal, The Elon Journal of Undergraduate in Communication, Vol.(3),no.(2), p 62-75

[20] Chorles Amcclelland The Beginning Durationantional Abatement of international Crisis in Charles Herman. Cit, p. 4.

[21] . Cooley, 2011) "An examination of the situational crisis communication the dry through the general motors' bankruptcy

[22] Yamamoto \& Sekeroglu.2011) Crisis management in the Turkish leather industry 